\title{
Ortaokul 8. Sınıf Öğrencilerinin Çoklu Zekâ Algıları ve Matematik Öğretim Programında Yer Alan Alana Özgü Problem Çözme Becerileri Arasındaki İlişkinin İncelenmesi ${ }^{1}$
}

\section{Examining the Relationship between 8th Graders' Perceptions of the Multiple Intelligence and Field-Specific Problem Solving Skills Included in the Math Curriculum}

Öz

\author{
Hatice YILDIZ², Merve CEYLAN ${ }^{3}$
}

Bu araştırmanın amacl; Sivas il merkezindeki ortaokul 8.sınıf öğrencilerinin çoklu zekâ alanlarına ilişkin algılarını ve Illköğretim Matematik Dersi Öğretim Programı (IMDÖP)'nda yer alan alana özgü problem çözme becerilerini belirlemek, çoklu zekâ alanlarına ilişkin algılarını ve IMDÖP'te yer alan alana özgü problem çözme becerilerini cinsiyet değişkeni açısından incelemek; ayrıca bu algı ve beceri arasındaki ilişkiyi tespit etmektir. Araştırmanın örneklemi, basit seçkisiz örnekleme yöntemi ile seçilmiş olan 656 ortaokul 8. sınıf öğrencisinden oluşmaktadır. Araştırmada nicel araştırma yöntemlerinden ilişkisel tarama modeli kullanılmıştır. Araştırmada veriler Oral (2001) tarafından Türkçe'ye uyarlama çalışması yapılan "Çoklu Zekâ Envanteri" ve araştırmacı tarafından geliştirilen "Problem Çözme Beceri Testi" ile toplanmıştır. Verilerin analizinde SPSS 18, Jmetrik 4.0 ve Lisrel 8.8 paket programları kullanılmışır. Araştırma sonucunda, ortaokul 8. sınıf öğrencilerinin algılarına göre en yüksek olduğunu düşündükleri zekâ alanı mantıksal-matematiksel zekâ alanıdır. Bu zekâ alanını kişilerarası ve görsel-uzamsal zekâ alanı izlemektedir. En düşük olduğunu düşündükleri zekâ alanı müziksel-ritmik zekâ olarak bulunmuştur. Öğrencilerin iMDÖP'te yer alan alana özgü problem çözme becerileri ve çoklu zekâ alanlarına ilişkin algıları cinsiyete göre farklıık göstermektedir. Öğrencilerin IMDÖP'te yer alan alana özgü problem çözme becerileri ile sözel-dilsel, mantıksal-matematiksel ve görsel-uzamsal zekâ alanlarına ilişkin algıları arasında pozitif yönlü ve orta düzeyde; müziksel-ritmik zekâ alanına ilişkin algıları arasında negatif yönlü ve orta düzeyde ilişki bulunmuştur. Çoklu zekâ alanları birlikte, iMDÖP'te yer alan alana özgü problem çözme becerisindeki toplam varyansın \%44'ünü açıklamaktadır. Problem ç̧̈zme becerisi için; mantıksal-matematiksel zekâ orta düzeyde ve pozitif anlamlı yordayıcı, müziksel-ritmik zekâ düşük düzeyde ve negatif anlamlı yordayıcı olarak bulunmuştur.

\section{Anahtar Kelimeler: Çoklu zekâ algııı, ilköğretim matematik dersi öğretim programı, problem çözme becerileri}

\section{Abstract}

This study aims to identify the perceptions of 8th-grade students related to the multiple intelligence fields and field-specific problem solving skills included in the Elementary Math Curriculum (EMC), to examine the variation in perceptions of multiple intelligence and field-specific problem solving skills included in the EMC brought by gender, and to establish the relationship between these perceptions and skills in the 8th graders in central Sivas. The sample of the study comprised 656 8th graders selected using a simple random sampling method. The study adopts a correlational survey design, which is a quantitative research method, and data for the study was collected using "Multiple Intelligences Inventory", adapted for Turkish by Oral (2001), the "Problem Solving Skills Test" developed by the researchers. The collected data was analyzed using the SPSS 18, Jmetrik 4.0 and Lisrel 8.8 software packages. The 8th grade students were found to have the highest level of perceived intelligence in the logicalmathematical field, followed by interpersonal and visual-spatial fields. The lowest level of perceived intelligence among the students was found to be in the musical-rhythmic field. The students' perceptions of multiple intelligence fields and field-specific problem solving skills included in the EMC varied between genders. The field-specific problem solving skills included in the EMC were found to have positive and moderate relationships with the verbal-linguistic, logical-mathematical and visual-spatial intelligence fields and a negative and moderate relationship with the musical-rhythmic field. Together, the multiple intelligence fields explain 44 percent of the total variance in the field-specific problem solving skills included in the EMC. Logical-mathematical intelligence was found to be a moderate and positive significant predictor for problem solving skills, while musical-rhythmic intelligence was found to be a weak and negative significant predictor.

Keywords: Multiple intelligence perception, elementary math curriculum, problem solving skills

${ }^{1}$ Bu çalışma Merve Ceylan'ın Dr. Öğr. Üyesi Hatice YILDIZ danışmanlığında tamamladığı yüksek lisans tezinin bir bölümünden oluşmaktadır. ${ }^{2}$ Sivas Cumhuriyet Üniversitesi, Eğitim Fakültesi, Eğitim Bilimleri Bölümü, Sivas, Türkiye. https://orcid.org/0000-0003-2365-6937

${ }^{3}$ Sivas Milli Eğitim Müdürlüğü, Sivas, Türkiye.

Atıf / Citation: Yıldız, H., \& Ceylan, M. (2020). Ortaokul 8. Sınıf öğrencilerinin çoklu zekâ algıları ve matematik öğretim programında yer alan alana özgü problem çözme becerileri arasındaki ilişkinin incelenmesi. Kastamonu Education Journal, 28(2), 777-792. doi:10.24106/kefdergi.702845 


\section{Extended Abstract}

Purpose of the Study: Education has a vital importance for all countries. In order to achieve quality in education and to provide a qualified education to the society, it is necessary to prepare the learning processes and environments that will enable the individual differences to be taken into consideration and to work in the activities for the intelligence field where each individual is competent (Demir, 2016).

One of the theories that take individual differences into consideration is the Multiple Intelligence Theory. The Multiple Intelligence Theory emphasizes that students have different interests and potentials and that the educational activities to be carried out should be organized by taking into account the areas where the students are competent (Gardner, 2004).

One of the most important aims of contemporary education programs is to teach using the theories and methods that take into account individual differences such as multiple intelligence theory. Another is to provide students with problem solving skills in mathematics or other courses. Problem solving ability helps both individuals to adapt to social life and to contribute to social development of individuals. As the problem solving skill is used in many fields and in different ways, this skill is included in all curricula. Because of this importance, it is considered as a worthwhile study to investigate the relationship between problem solving ability and multiple intelligence perception. In this study, 8th grade students' multiple intelligence perceptions and field-specific problem solving skills included in the Elementary Math Curriculum (EMC) were examined and the relationship between them was investigated.

Method: The sample of the study comprised 656 8th graders selected using a simple random sampling method. The study adopts a correlational survey design, which is a quantitative research method, and data for the study was collected using "Multiple Intelligences Inventory", adapted for Turkish by Oral (2001), the "Problem Solving Skills Test" developed by the researchers.

Results and Conclusions: The 8th grade students were found to have the highest level of perceived intelligence in the logicalmathematical field, followed by interpersonal and visual-spatial fields. The lowest level of perceived intelligence among the students was found to be in the musical-rhythmic field. Gürses (2011), Bulut (2003) and Erman (2003) support this conclusion. In these researches, logical-mathematical, interpersonal and visual-spatial intelligence areas were high, somatic-kinesthetic intelligence and musicalrhythmic intelligence areas were low. The logical inferences of the students in solving the problems faced in daily life and the fact that mathematics has a significant contribution to the evaluation of the Transition to High Schools exam in the 8th grade may have played a role in the higher perception of students in logical-mathematical intelligence areas. The fact that elementary level students are interested in color visuals and materials can be effective in their perception of visual-spatial intelligence. The reason why students' perceptions of musical-rhythmic intelligence was low was that the lessons that students would develop in these areas of wisdom were low in the secondary school curriculum or the hours of these courses were low. However, not only the students' mathematical and verbal intelligence, but also other areas of intelligence should be developed in the classroom. For this purpose, teachers can make lessons more interesting by teaching music or singing or adapting techniques such as acting and drama to mathematical problems. In other words, teachers should prepare all course activities and materials considering all intelligence areas.

The students' perceptions of verbal-linguistic, logical-mathematical, visual-spatial and internal intelligence levels differed significantly according to gender variables. This difference was in favor of female students. Female students' perceptions about verballinguistic, logical-mathematical, visual-spatial and internal intelligence levels were higher than male students. The results of the research by Yenilmez and Çalışkan (2011), Çamurcu Nuhoğlu (2007), Yaz (2013) and Kabataş (2006) support the findings of this research. Female students' perceptions of logical-mathematical intelligence areas higher than male students may be due to the higher participation of female students in educational activities and the fact that girls are more interested in educational activities (courses, exhibitions, projects, etc.). Female students being interested in beauty and aesthetics, paying attention to the details of the visuals may have been effective in increasing the perceptions of visual-spatial intelligence. Female students being more emotional than male students and investigating the events in detail can be effective in the perception of internal intelligence as higher than the perception level of male students (Şahin, 2007). In line with these results, male students should be given more duties and responsibilities in the classroom environment in order to increase their skills in low intelligence areas.

The students were successful in the field-specific problem-solving skills in the EMC. The fact that the students participating in the research was preparing for the Transition to High Schools exam and taking part in activities to solve the problems in the mathematics course from the elementary school can be effective in this problem-solving scores.

The students' field-specific problem solving skills included in the EMC varied between genders. This difference was in favor of girls. In a study conducted by Carr, Jessup and Fuller (1999), it was found that female students' problem solving performance was better than that of male students.

The field-specific problem solving skills included in the EMC were found to have positive and moderate relationships with the verbal-linguistic, logical-mathematical and visual-spatial intelligence fields and a negative and moderate relationship with the musicalrhythmic field. Together, the multiple intelligence fields explain 44 percent of the total variance in the field-specific problem solving skills included in the EMC. Logical-mathematical intelligence was found to be a moderate and positive significant predictor for problem solving skills, while musical-rhythmic intelligence was found to be a weak and negative significant predictor. Dursun and Dede (2004) stated that the logical-mathematical intelligence of the students was an important factor in the mathematics achievement. The fact that the students did not have an activity towards musical-rhythmic intelligence in the process of mathematical problem solving and lack of studies on musical intelligence in mathematics courses may have caused the musical-rhythmic intelligence to be a weak and negative significant predictor of field-specific problem-solving skills in the EMC. 


\section{Giriş}

Hızlı bir değişim içinde bulunan dünya, başta eğitim olmak üzere her konudaki yenilik ve gelişmeleri takip eden, toplum içinde üzerine düşen görevlerin farkında olan ve bu görevlerini yerine getiren bireylere ihtiyaç duymaktadır. Dünya üzerindeki tüm ülkelerde bu bireyleri yetiştirmek için kaliteli bir eğitim gerekmektedir. Çünkü, eğitim ülkeler için hayati bir önem taşımaktadır. Eğitimde kaliteyi yakalamak ve topluma nitelikli bir eğitim sunmak için başarılı eğitim programlarına intiyaç vardır. Eğitim programlarının başarıya ulaşması, bireysel farklılıkları bir avantaj olarak kullanıp, her bireyin yetkin olduğu zekâ alanına yönelik etkinliklerde çalışmasını sağlayabilecek şekilde öğrenme süreç ve ortamlarının hazırlanmasından geçmektedir (Demir, 2016).

Bireysel farklııkların dikkate alındığı bir öğretim sürecinin nasıl gerçekleştirileceği ile ilgili birçok görüş ortaya atılmıştır. Alanyazını incelendiğinde; bireysel farklılıkları dikkate alan farklı öğretim yöntemleri, stratejileri ve kuramları ile karşılaşılmaktadır. Bu kuramlardan biri de Çoklu Zekâ Kuramı'dır. Çoklu Zekâ Kuramı, öğrencilerin farklı ilgi alanlarına ve potansiyellere sahip olduğunu, yapılacak eğitim faaliyetlerinin öğrencilerin yetkin oldukları alanların dikkate alınarak düzenlenmesi gerektiğini vurgulamaktadır (Gardner, 2004). Çoklu Zekâ Kuramı́nın çıkış noktası, bireylerin farklı ilgi ve yeteneklerinin ayrı ayrı ele alınarak eğitim ortamının ezbercilikten uzak, uygulama ve çeşitlilik açısından zengin bir şekilde oluşturulmasını sağlamaktır.

Bir öğretim programı hazırlanırken veya bir öğretme faaliyeti planlanırken öğrencilerin bireysel ihtiyaçları, ilgileri, öğrenme tercihleri, öğrenmede güçlük çektikleri konular veya kavramlar, dilleri ve kültürleri dikkate alınmalıdır (Azar, Presley ve Balkaya, 2006). Etkili ve verimli bir eğitim-öğretim sürecinin belirtisi, öğrencilerin sahip oldukları özelliklerinin fark edilmesi ve bu farklılıklara uygun öğretim ortamlarının sağlanmasıdır. İyi bir öğretim programı öğrenciler arasındaki farklılıkları azaltmak yerine artırmalıdır (Kanat, 2008). Aynı sınıf seviyesinde bulunan öğrencilerin her birinin zekâ alanı farklılık göstermektedir. Bu durum, öğrencilerin sınıf içi etkinliklerden benzer düzeylerde faydalanmalarını etkilemektedir. Geleneksel öğretim yöntemlerinde tek tip öğretim uygulandığı için farklı zekâ alanlarına sahip öğrenciler dersi anlama noktasında sorunlar yaşamaktadırlar (Yenilmez ve Bozkurt, 2006). Öğrencilerin sahip oldukları farklı özellikleri dikkate alan yapılandırmacı yaklaşıma göre eğitim sürecinde amaç, bilgiyi öğrencilere ezberletmek değil, onların bilişsel gelişimlerine göre öğrenmelerine katkıda bulunmaktır (Şengül ve Öz, 2008).

Çoklu Zekâ Kuramı, eğitim sürecini zenginleştirmekte, eğitimin niteliğini artırmakta; diğer derslerde olduğu gibi matematik dersinde de her bireyin öğrenebileceği şekilde etkinlikler sunmaktadır. Bu sayede; öğrenciler matematiği, öğrenmekte zorlandıkları bir ders olarak algılamayacak ve kendi öğrenme yöntemlerine yönelik düzenlenecek etkinliklerle daha eğlenceli bir ders olarak düşüneceklerdir (Şengül ve Öz, 2008). Öğrenciler, matematik öğrenirken bilgileri sorgulayıp, neden-sonuç bağlantıları kurabilecektir. Karşılaştıkları problemlere farklı çözüm yolları bulup, üzerinde düşünüp yeni fikirler üretebileceklerdir.

Matematik öğretiminin temel amaçlarından biri de problem çözme becerisi kazandırmaktır (Milli Eğitim Bakanlığı [MEB], 2009). Problem çözme becerisi, hem bireylerin toplumsal yaşama uyum sağlamalarına hem de bireylerin toplumsal kalkınmaya katkıda bulunmalarına yardımcı olur. Bu nedenle; çağdaş eğitim programlarının en önemli amaçlarından biri öğrencilerin matematik, fen bilgisi gibi çeşitli alanlarda problem çözme becerilerini geliştirmektir (Erden, 1986). Cockroft'a (1982) göre problem çözme matematik öğretiminin özünü oluşturmaktadır (Akt. Bayazit ve Aksoy, 2009). Problem çözme sürecinde öğrenciler, problemi formüller ile ifade ederler; probleme uygun modeller geliştirirler; probleme ait bilgileri arasında ilişki kurarlar; farklı metot ve stratejiler geliştirirler; aritmetiksel ve cebirsel işlemler yaparlar ve bu şekilde matematiksel bilgilerini uygulamaya çalışırlar. Problem çözme becerisi okul öncesi eğitimden üniversite düzeyine kadar matematik programının önemli bir parçasıdır (Bayazit ve Aksoy, 2009).

İlköğretimde problem çözme davranışlarının geliştirilmesine dönük bir yaklaşım izlenmesi, öğrencilerin problem çözmedeki başarılarına, matematiğin esaslarını ve konularını daha iyi kavramalarına ve matematiğe karşı olumlu tutum geliştirmelerine yardımcı olacaktır (Baykul, 2002). Problem çözme becerisi, birçok alanda ve farklı şekillerde kullanıldığı için bu beceriye bütün öğretim programlarında yer verilmiştir. Matematiksel problem çözme becerisinin her kademedeki matematik öğretim programlarının merkezinde yer almasının en önemli nedeni; genelde öğrenmeyi, özelde ise matematiği anlamayı ve matematiksel düşünceyi geliştirmesidir (Schoenfeld, 1985). Yapılan bu araştırma matematik öğretim programlarında Çoklu Zekâ Kuramı [ÇZK]'nın dikkate alınması ve uygulanması hususunda bir farkındalık yaratması açısından önem taşımaktadır. Bu araştırma, iMDÖP'ün uygulayıcısı olan öğretmenlerin, öğrencilerin farklı zekâ alanlarını dikkate almaları ve yapılan etkinlikleri farklı zekâ alanlarına göre düzenlemeleri için fikir vermesi açısından önemlidir. Problem çözme, matematik öğretiminin temel taşını oluşturmaktadır (NCTM, 
2000). Öğrencilerin ilköğretim matematik dersi öğretim programının temel taşı olan problem çözme becerilerine ait bilgi vermesi açısından bu çalışma önemlidir. Alanyazını incelendiğinde, öğrencilerin problem çözme becerilerinin likert tipi envanterler ile araştııılığı ya da problem çözme becerisine ait sadece bir strateji ile çalışma yapıldığı tespit edilmiştir. Bu çalışmada ise, öğrencilerin iMDÖP'te yer alan alana özgü problem çözme becerileri iMDÖP'te yer alan problem çözme stratejilerine göre oluşturulmuş problemler ile belirlenmiştir. Bu çalışmanın sonucu, araştırmacılara, bu çalışmadan sonra matematik dersindeki problem çözme becerisi ile ilgili yapılacak olan çalışmalara yardımcı olması ile önem taşımaktadır.

Bu öneminden dolayı problem çözme becerisinin çoklu zekâ algısı gibi farklı değişkenlerle ilişkilendirilip incelenmesi araştırmaya değer bir konu olarak görülmektedir. Bu görüşten hareketle yapılan bu çalışmada ortaokul 8. sınıf öğrencilerinin IMDÖP'te yer alan alana özgü problem çözme becerileri ve çoklu zekâ alanlarına ilişkin algıları incelenmiş ve aralarındaki ilişki araştırımıştır. Bu araştırmanın problem cümlesi "8. sınıf öğrencilerinin çoklu zekâ alanlarına ilişkin algıları ile iMDÖP'te yer alan alana özgü problem çözme becerileri arasında anlamlı düzeyde bir ilişki var mıdır?" şeklinde ifade edilmiştir. Araştırmanın alt problemleri şu şekildedir:

Ortaokul 8. sınıf öğrencilerinin;

1. Çoklu zekâ alanlarına ilişkin algıları nedir?

2. Çoklu zekâ alanlarına ilişkin algıları cinsiyet değişkenine göre farklılaşmakta mıdır?

3. IMDÖP'te yer alan alana özgü problem çözme becerileri ne düzeydedir?

4. iMDÖP'te yer alan alana özgü problem çözme becerileri cinsiyet değişkenine göre farklılaşmakta mıdır?

5. Çoklu zekâ alanlarına ilişkin algıları ile iMDÖP'te yer alan alana özgü problem çözme becerileri arasında anlamlı düzeyde bir ilişki var mıdır?

6. Çoklu zekâ alanlarına ilişkin algıları iMDÖP'te yer alan alana özgü problem çözme becerisini yordamakta midır?

\section{Yöntem}

\section{Araştırmanın Modeli}

Bu araştırmada, ortaokul öğrencilerinin çoklu zekâ algıları ile alana özgü problem çözme becerileri arasındaki ilişkinin belirlenmesi amaçlandığından betimsel tarama modellerinden ilişkisel tarama yöntemi kullanılmıştır. Tarama modeli, bir grubun belirli özelliklerini ortaya çıkarmak için verilerin toplanmasını amaçlayan araştırmalardır (Büyüköztürk, Çakmak Kılıç, Akgün, Karadeniz ve Demirel, 2014). Genel tarama modelleri sadece bir değişkenin incelendiği ya da değişkenlerin tek tek incelendiği tekil tarama modelleri ile iki ya da daha çok sayıda değişkenin aralarındaki ilişkilerin de belirlenmek üzere incelendiği ilişkisel tarama modelleridir. iliş̧kisel tarama modelleri, iki ya da daha fazla değişken arasında birlikte değişimin varlığını veya derecesini belirlemeyi amaçlayan araştırma modelleridir. Korelasyon türü araştırmalarda değişkenlerin birlikte değişip değişmedikleri, birlikte bir değişme varsa, değişmenin ne yönde ve ne kadar güçlü olduğu öğrenilmeye çalışılır (Karasar, 2003). Öğrencilerin çoklu zekâ alanlarına ait algıları ile alana özgü problem çözme becerileri arasındaki ilişkiyi kontrol etmek için korelasyon katsayıları hesaplanmıştır.

\section{Evren ve Örneklem}

Bu araştırmanın evrenini, Sivas il merkezinde Milli Eğitim Bakanlığı'na bağlı ortaokullarda öğrenim gören 4498 8. sınıf öğrencisi oluşturmaktadır. Araştırmanın örneklemi, 2016-2017 eğitim-öğretim yılında Sivas İ Milli Eğitim Müdürlüğü’ne bağlı ortaokullarda öğrenim gören 656 8. sınıf öğrencisinden oluşmaktadır. Örneklem seçiminde; seçkisiz örnekleme yöntemlerinden basit seçkisiz örnekleme yöntemi kullanılmıştır. Sivas ilı Milli Eğitim Müdürlüğü'ne bağlı 5 eğitim bölgesi bulunmaktadır. 1. eğitim bölgesinde ortaöğretim kurumları olduğu için 1. eğitim bölgesinden örneklem seçilmemiştir. Araştırmanın örneklemini, 2016-2017 eğitim-öğretim yılında 4 eğitim bölgesinden (2. eğitim bölgesi, 3. eğitim bölgesi, 4. eğitim bölgesi, 5. eğitim bölgesi), her bölgeden 3 ortaokul olmak üzere toplam 12 tane devlet okulunda öğrenim gören 8. sınıf öğrencisi oluşturmuştur. Araştırmaya katılan 656 öğrenciden 331'i $(\% 50,5)$ kız, 325'i de (\% 49,5) erkektir.

\section{Veri Toplama Araçları}

Araştırmanın verileri "Problem Çözme Becerisi Testi” ve "Çoklu Zekâ Envanteri” ile toplanmıştır. 


\section{Problem Çözme Beceri Testi}

Problem çözme beceri testinin amacı, öğrencilerin problem çözme becerilerini ölçebilmektir. Problem Çözme Beceri testi geliştirilirken ilk olarak IMDÖP'te yer alan alana özgü problem çözme becerisinin içeriği incelenmiştir. IMDÖP'te yer alan alana özgü problem çözme becerilerine yönelik verilen stratejiler incelenmiştir. Bu stratejiler (MEB, 2009):

1. Deneme-yanılma

2. Şekil, resim, tablo vb. kullanma

3. Materyal (malzeme) kullanma

4. Sistematik bir liste oluşturma

5. Örüntü arama

6. Geriye doğru çalışma

7. Tahmin ve kontrol etme

8. Varsayımları kullanma

9. Problemi başka bir biçimde ifade etme

10. Problemi basitleştirme

11. Problemin bir bölümünü çözme

12. Benzer bir problem çözme

13. Akıl yürütme

14. İşlem seçme

15. Denklem kullanma

16. Canlandırma şeklindedir.

Problem çözme beceri testi geliştirmek amacıyla öncelikle araştırmacı tarafından her stratejiyi kapsayacak şekilde toplam 43 soru hazırlanmıştır (Deneme-yanılma 3 soru, Şekil, resim, tablo vb. kullanma 4 soru, Materyal (malzeme) kullanma 3 soru, Sistematik bir liste oluşturma 3 soru, Örüntü arama 3 soru, Geriye doğru çalışma 3 soru, Tahmin ve kontrol etme 3 soru, Varsayımları kullanma 3 soru, Problemi başka bir biçimde ifade etme 3 soru, Problemi basitleştirme 2 soru, Problemin bir bölümünü çözme 1 soru, Benzer bir problem çözme 2 soru, Akıl yürütme 3 soru, İşlem seçme 3 soru, Denklem kullanma 3 soru, Canlandırma 1 soru). Hazırlanan taslak problem çözme beceri testi kapsam ve görünüş geçerliliği için Sivas il merkezinde görev yapan 4 matematik öğretmeni, üniversitede matematik alanında görev yapan 1 öğretim üyesi ve matematik eğitimi alanında görev yapan 1 öğretim üyesinin görüşleri alınarak düzenlenmiştir. Uzman görüşü alındığında; öğretmenler "Olasılık" öğrenme alanının sadece 8. sınıfın matematik dersi programında yer aldığını ve 8. sınıfta bütün stratejilere ait problemlerin artık işlenmiş olacağını belirtmişlerdir. Bu görüşlerden hareketle, çalışmanın 8. Sınıf öğrencileriyle yapılmasına karar verilmiştir. Başarı testinin ön uygulaması için gerekli kişi sayısı en az 120 olmak üzere 400 kişi olması önerilmektedir (Özçelik, 2016). Ön uygulama Sivas il merkezinde bulunan Süleyman Demirel Ortaokulu'nda öğrenim gören 201 8. sınıf öğrenci ile gerçekleştirilmiştir. Ön uygulama, iki ders saati süresince iki hafta boyunca araştırmacı tarafından yapılmıştır. Daha sonra uygulanan taslak problem çözme beceri testine ait cevap anahtarında doğru yanıtlar 1, yanlış yanıtlar 0 olarak puanlanmış ve veri kaybı açııından dikkatlice kontrol edilerek veri kaybı olmadığı tespit edilmiştir. Bu aşamada; teste verilen tüm yanıtlar geçerli kabul edilerek J-metrik 4.0 programında madde analizi yapılmıştır. Yetenek testleri, başarı testleri gibi bilgi ve becerilerin ölçüldüğü testlerde yer alan maddelerin doğru cevaplanma oranını gösteren madde güçlüğü, testin son formu için madde seçiminde de bir ölçüt olarak kullanılır. Madde güçlük indeksi için 0,00-0,20 arası çok zor, 0,21-0,40 arası zor, 0,41-0,60 arası orta güçlükte, 0,61-0,80 arası kolay, 0,81-1,00 arası testin çok kolay olduğu kabul edilmektedir. Madde güçlüklerinin 0,50 civarında olması beklenir (Kılıç, 2015). Ön uygulamada madde güçlük indeks değerleri 0,48 ile 0,92 arasında bulunmuştur. Madde ayırt ediciliği, maddelerin ölçülen özellikle ilgili olarak öğrencileri ne derece ayırt ettiğini göstermektedir. Testin ölçmeyi amaçladığı özelliğe yüksek düzeyde sahip olan öğrencilerle, düşük düzeyde sahip olan öğrencileri ayırt etme gücüdür. Madde ayırt edicilik indeksi (rjx) -1,0 ile $+1,0$ arasında değişmektedir. Madde ayırt edicilik indeksi 1'e yaklaştıkça maddenin ayırt edicilik gücü artmaktadır (Büyüköztürk vd., 2014). Ön uygulamada madde ayırt edicilik indeks değerleri 0,32 ile 0,61 arasında değişmiştir. Bu durum, madde ayırt edicilik indeksinin yüksek olduğunu göstermektedir. Ön uygulama sonucunda testte yer alan maddelerin ayırt edicilikleri ve güçlükleri incelenmiş, testten çıkarılacak madde görülmemiştir. Fakat soru sayısının fazla olmasından dolayı, öğrencilerin yorulacağı ve çözerken sıkılacağı düşüncesinden hareketle; uzman görüşü doğrultusunda testin kullanışlılı̆ını artırmak için kapsam geçerliliğine dikkat edilerek madde sayısı 30'a düşürülmüştür. Testten madde çıkarılmasında ayırt edicilikleri diğer maddelere göre daha düşük olan maddeler tercih edilmiştir. Ön uygulamada ortaya çıkan madde güçlük indeksi de değerlendirilerek testten 13 madde $(1,4,10$, $13,14,17,19,24,25,30,32,36,37)$ çıkarılmışır. 
Ön uygulamada testin güvenirlik katsayısı (KR-21) 0,92 ve testin ortalama güçlüğü Pj=0,70 bulunmuştur. Her bir maddenin güvenirlik değeri hesaplanmıştır. Her bir maddenin güvenirlik değerleri 0,92-0,93 değerlerinde bulunmuştur. 30 maddelik nihai test 656 8. sınıf öğrencisine uygulanmıştır.

Nihai test maddelerinin madde güçlük indeksleri (Pj) 0,51 ile 0,83 arasındadır. Bu da soruların orta güçlük ve üzerinde olduğunu göstermektedir. Nihai testin ortalama güçlüğü $\mathrm{Pj}=0,68$ bulunmuştur. Yani test bütün olarak değerlendirildiğinde orta güçlük düzeyindedir. Nihai teste ait madde ayırt edicilik indeksleri (rjx) 0,33 ile 0,53 arasındadır. Bu değerler test maddelerinin ayırt edicilik indekslerinin yüksek olduğunu göstermektedir. Nihai testin ortalaması $=20,50$ ve standart sapması $S j=6,47$ bulunmuştur.

Güvenirlik, bir ölçme aracının hatalardan arınık olmasının ve tutarlılığının göstergesidir (Balcı, 2009). Testin güvenirliğinin belirlenmesi için KR-21 formülü kullanılmıştır. KR-21 formülünün tek uygulamaya dayalı bir yöntem olması maddelerin hatırlanması gibi riskleri ortadan kaldırmaktadır (Crocker ve Algina, 2008'den Akt. Kılıç, 2015; Köse, 2012). KR-21 kapsam örnekleme hatasına ve madde heterojenliğine duyarlı bir güvenirlik belirleme yöntemidir (Köse, 2012). Nihai testin güvenirlik katsayısı (KR-21) 0,88 bulunmuştur. Her bir maddenin güvenirlik değeri hesaplanmıştır ve güvenirlik değerleri 0,87 ve 0,88 olarak çıkmıştır. Geliştirilen problem çözme beceri testinin orta güçlük düzeyinde, iyi ayırt ediciliğe sahip ve yüksek güvenirlikte olduğu belirlenmiştir.

Problem çözme beceri testinden alınabilecek en küçük puan 0 ve en yüksek puan 30'dur. Ortaokul 8.sınıf öğrencilerinin problem çözme becerileri hakkında bir yargıya varmak için testten elde edilen puanlar, "düşük”, "orta” ve "yüksek" şeklinde üçlü sınıflamaya tabi tutulmuştur. Bu sınıflamanın belirlenmesinde esas alınan puan aralıkları problem çözme beceri testinin geneli için; 0-10 puan arası "düşük", 11-20 puan arası "orta" ve 21-30 puan arası "yüksek" düzeyde problem çözme becerisini göstermektedir.

\section{Çoklu Zekâ Envanteri}

Araştırmada öğrencilerin çoklu zekâ algılarını belirlemek amacıyla Oral (2001) tarafından Türkçe’ye uyarlama çalışması yapılan “Çoklu Zekâ Envanteri” kullanılmıştır. Çoklu Zekâ Envanteri 8 zekâ alanının her birine yönelik 10’ar cümleden oluşan toplam 80 maddeden oluşmaktadır. Oral (2001)’ın çalışmasında Çoklu Zekâ Envanteri'nde elde edilen Cronbach Alpha iç tutarlılık katsayısı envanterin tamamı için 0,90, alt boyutları; bedensel-kinestetik zekâ 0,60; kişilerarası zekâ 0,62; içsel zekâ 0,63; mantıksal-matematiksel zekâ 0,62; müziksel-ritmik zekâ 0,79; sözel-dilsel zekâ 0,62; görsel-uzamsal zekâ 0,60 ve doğa zekâsı zekâ 0,63'tür.

Bu çalışmada ölçeğin alt boyutları için hesaplanan Cronbach Alpha güvenirlik değerleri sırasıyla sözel-dilsel zekâ için 0,81; mantıksal-matematiksel zekâ için 0,89; görsel-uzamsal zekâ için 0,85; bedensel-kinestetik zekâ için 0,85; müziksel-ritmik zekâ için 0,88; kişilerarası zekâ için 0,73 ; içsel zekâ için 0,77 ; doğacı zekâ için $0,88^{\prime}$ dir. Envanterin tamamı için Cronbach Alpha güvenirlik değeri 0,91'dir.

Çoklu Zekâ Envanteri'nin sekiz boyutlu yapısının doğrulanması için bu araştırmanın nihai verileriyle, Doğrulayıcı Faktör Analizi (DFA) yapıımıştır. DFA sonuçları Tablo 1' de verilmiştir.

Tablo 1. Çoklu Zekâ Envanteri'nin uyum indekslerine ilişkin mükemmel ve kabul edilebilir uyum değerleri ile DFA'dan elde edilen uyum indeksi değerleri

\begin{tabular}{ccccc}
\hline $\begin{array}{c}\text { Incelenen Uyum } \\
\text { Inndeksleri }\end{array}$ & $\begin{array}{c}\text { Mükemmel Uyum } \\
\text { Ölçütleri }\end{array}$ & $\begin{array}{c}\text { Kabul Edilebilir } \\
\text { Uyum Ölçütleri }\end{array}$ & $\begin{array}{c}\text { DFA'dan } \\
\text { Elde } \\
\text { Edilen Uyum } \\
\text { Indeksileri }\end{array}$ & Sonuç \\
\hline $\mathrm{X}^{2} / \mathrm{sd}$ & $0 \leq \mathrm{X}^{2} / \mathrm{sd} \leq 2$ & $2 \leq \mathrm{X}^{2} / \mathrm{sd} \leq 3$ & 1,935 & $\begin{array}{c}\text { Mükemmel Uyum } \\
\text { RMSEA }\end{array}$ \\
$\mathrm{CFI}$ & $0,00 \leq \mathrm{RMSEA} \leq 0,05$ & $0,05 \leq \mathrm{RMSEA} \leq 0,08$ & 0,038 & $\begin{array}{c}\text { Mükemmel Uyum } \\
\text { Kabul Edilebilir } \\
\text { Uyum }\end{array}$ \\
$\mathrm{NFI}$ & $0,95 \leq \mathrm{CFI} \leq 1,00$ & $0,90 \leq \mathrm{CFI} \leq 0,95$ & 0,908 & $\begin{array}{c}\text { Kabul Edilebilir } \\
\text { Uyum }\end{array}$ \\
\hline
\end{tabular}

(Kline, 2011; Browne \& Cudeck, 1993; Baumgartner \& Homburg, 1996; Akt. İlhan ve Çetin, 2014).

Tablo 1 incelendiğinde, sekiz boyutlu modelin iyilik uyum indekslerinin kabul edilebilir düzeyde olduğunu belirlenmiştir. Çoklu Zekâ Envanteri'nin 8 boyutlu yapısı doğrulanmıştır. 


\section{Verilerin Toplanması ve Analizi}

Veri toplama sürecinde ilk olarak çalışma ile ilgili alan yazın taraması yapılmış, kullanılacak ölçme araçlarına karar verilmiştir. Araştırma için verilerin toplanması amacıyla Sivas îl Milli Eğitim Müdürlüğü’nden gerekli izinler alınmıştır. Araştırma, 4 Eğitim Bölgesinden her bölgeden 3 ortaokul olmak üzere 12 ortaokulda 656 8. sınıf öğrencisi ile araştırmacı tarafından gerekli açıklamalar yapıldıktan sonra gerçekleştirilmiştir. Uygulama esnasında öğrencilerin sorularına gerekli açıklamalar yapılmıştır. Araştırmadan elde edilen veriler, SPSS 18 programı kullanılarak analiz edilmiştir. Çoklu Zekâ Envanteri'nin geçerlik çalışması için Lisrel 8.8 programı kullanılarak doğrulayıc faktör analizi yapılmıştır. Problem Çözme Beceri Testi'nin geliştirilmesinde madde analizi için J-metrik 4.0 programı kullanılmıştır.

Çoklu Zekâ Envanteri ve iMDÖP'te yer alan alana özgü Problem Çözme Beceri Testi'nin normallik varsayımının test edilmesinde Kolmogorov-Smirnov testi kullanılmıştır. Ayrıca Çarpıklık (Skewness) ve Basıklık (Kurtosis) katsayıları da incelenmiştir. Çarpıklık katsayısının \pm 1 sınırları içinde kalması, basıklık katsayının \pm 2 sınırları içinde kalması puanların normal dağılımdan önemli bir farklılık göstermediği şeklinde yorumlanabilir (Baykul ve Güzeller Oktay, 2014). Araştırmada Çoklu Zekâ Envanteri ve Problem Çözme Beceri Testi için çarpıklık değerleri sırasıyla -0,399 ve 0,240 bulunmuştur. Çoklu Zekâ Envanteri ve Problem Çözme Beceri testi için basıklık değerleri sırasıyla -0,171 ve 1,043 bulunmuştur. Her iki ölçekteki çarpıklık katsayıları \pm 1 , basıklık katsayısı da \pm 2 aralığında olduğu için normal dağılım olduğu kabul edilmiştir. Öğrencilerin zekâ alanlarına ilişkin algılarında ve problem çözme becerilerinde cinsiyetlerine göre farklılaşma olup olmadığının belirlenmesi için bağımsız gruplarda t-testi yapılmıştır. Öğrencilerin çoklu zekâ alanları ile problem çözme becerileri arasındaki ilişkiyi kontrol etmek için korelasyon katsayıları hesaplanmıştır. Korelasyon katsayısı 0,30'dan küçük ise ilişki zayıf; 0,30 ile 0,70 arasında ise orta düzeyde ve 0,70'den büyük ise yüksek düzeyde ilişki olduğu söylenebilir (Büyüköztürk, Köklü ve Çokluk, 2007).

Öğrencilerin çoklu zekâ alanlarına ait algılarının iMDÖP’te yer alan alana özgü problem çözme becerisini yordayıp yordamadığını belirlemek amacıyla çoklu doğrusal regresyon analizi yapılmıştır. Çoklu doğrusal regresyon analizi, bağımlı değişkenle ilişkili olan iki ya da daha fazla bağımsız değişkene dayalı olarak, bağımlı değişkenin tahmin edilmesine yönelik bir analiz türüdür (Baykul ve Güzeller Oktay, 2014; Büyüköztürk, 2014). Çoklu doğrusal regresyon analizi için bazı varsayımların sağlanması gerekmektedir. Çoklu doğrusal regresyon analizi için en az aralık ölçeğinde ölçülen sürekli değişken gereklidir (Büyüköztürk, 2014). Bu analizde yordayıcı değişken olarak çoklu zekâ alanları, bağımlı değişken olarak iMDÖP'te yer alan alana özgü problem çözme becerisi sürekli değişkenler olduğu için doğrudan kabul edilmiştir. Analizin bir başka varsayımı da yordayıcı değişkenlerle bağımlı değişken arasında doğrusal bir ilişkinin olmasıdır (Büyüköztürk, 2014). Bu nedenle çoklu zekâ alanları ve iMDÖP'te yer alan alana özgü problem çözme becerisi arasında doğrusallık ilişkisi test edilmiştir. Değişkenlerin çok değişkenli normal dağılım gösterip göstermediğine ilişkin inceleme yapılmıştır. Standartlaştırılmış hata değerlerine ilişkin grafikler incelenmiştir. Verilerde kayıp değer ve uç değer incelemesi yapılmış, kayıp değere rastlanmamıştır. Değişkenlerle ilgili uç değerlerin olup olmadığı incelenerek "normallik" ve "doğrusallık" varsayımı kontrol edilmiştir. Çoklu Zekâ Envanteri'nde ve Problem Çözme Beceri Testinde normallik ve doğrusallığın sağlandığı belirlenmiştir. Çoklu regresyon analizinde yordayıcı değişkenler arasında çoklu bağlantılııı olmaması gerekmektedir. Çoklu bağlantı, bağımsız değişkenler arasında yüksek düzeyde ilişkilerin olmasıdır. Veri deseninde çoklu bağlantının olup olmadığını incelemek için ilk olarak bağımsız değişkenler arasındaki ikili korelasyonlar incelenebilir. 0,80 üzerindeki korelasyon çoklu bağlantı olabileceğini gösterir (Büyüköztürk, 2014; Kalaycı, 2010). Bu durum için ikili korelasyonlar, Tolerans ve VIF değerleri incelenmiştir. İkili korelasyonlarda tüm değerler 0,80'den düşüktür. i̇kili korelasyon değerleri -0,364 ile 0,630 arasında değişmektedir. Tolerans değerinin 0,02 'den büyük, VIF değerinin ise $10^{\prime}$ dan küçük olması gerekmektedir (Kalaycı, 2010). Bu araştırmada, Tolerans değerleri 0,440 ile 0,901 arasında, VIF değerleri 1,110 ile 2,271 arasında bulunmuştur. Bu sonuçlara göre bağımsız değişkenler arasında korelasyon olmadığı yani çoklu bağlantılıık problemi olmadığı tespit edilmiştir. Otokorelasyonu test etmek için "Durbin Watson" katsayısı incelenmiştir. Durbin Watson değeri 0 ile 4 arasında değişmektedir. 0’a yakın değerler aşırı pozitif korelasyonu, 4'e yakın değerler aşırı negatif korelasyonu, 2'ye yakın değerler otokorelasyon olmadığını gösterir. Durbin Watson değerinin 1,5 ile 2,5 arasında olması beklenir (Kalaycı, 2010). Bu araştırmada Durbin Watson değeri 1,819 bulunmuştur. Varyans analizi sonucunda çoklu regresyon modeli anlamlı bulunmuştur.

\section{Bulgular}

Bu bölümde araştırmanın amaç ve alt amaçları yönünde elde edilen bulgulara yer verilmiştir.

\section{Öğrencilerin Çoklu Zekâ Alanlarına ilişskin Algıları}

Araştırmaya katılan öğrencilerin her bir zekâ alanına ait betimsel istatistik değerleri Tablo 2' de verilmiştir. 
Tablo 2. Öğrencilerin Çoklu Zekâ Alanlarına i̇lişkin Algılarına Ait Betimsel İstatistik Değerleri

\begin{tabular}{|c|c|c|c|c|c|c|}
\hline Zekâ Alanı & Madde Sayısı & $\mathbf{N}$ & Minimum & Maximum & $\overline{\mathbf{X}}$ & SS \\
\hline Sözel-Dilsel & 10 & 656 & 14,00 & 49,00 & 34,48 & 7,73 \\
\hline $\begin{array}{l}\text { Mantıksal- } \\
\text { Matematiksel }\end{array}$ & 10 & 656 & 12,00 & 50,00 & 37,08 & 8,38 \\
\hline $\begin{array}{l}\text { Görsel- } \\
\text { Uzamsal }\end{array}$ & 10 & 656 & 11,00 & 50,00 & 35,87 & 7,77 \\
\hline $\begin{array}{l}\text { Bedensel- } \\
\text { Kinestetik }\end{array}$ & 10 & 656 & 10,00 & 50,00 & 32,86 & 9,60 \\
\hline $\begin{array}{l}\text { Müziksel- } \\
\text { Ritmik }\end{array}$ & 10 & 656 & 11,00 & 50,00 & 29,81 & 9,26 \\
\hline Kişilerarası & 10 & 656 & 12,00 & 50,00 & 35,92 & 6,63 \\
\hline İçsel & 10 & 656 & 13,00 & 50,00 & 33,40 & 7,33 \\
\hline Doğacı & 10 & 656 & 11,00 & 50,00 & 32,34 & 9,37 \\
\hline
\end{tabular}

( $*^{*}$ < 05 anlamlılık düzeyi)

Tablo 2 incelendiğinde; öğrencilerin algılarına göre en yüksek olduğunu düşündükleri zekâ alanının mantıksalmatematiksel $\bar{X}=37,08$ (Ss=8,38) zekâ olduğu görülmektedir. Öğrencilerin yüksek olarak algıladıkları diğer zekâ alanları kişilerarası $\bar{X}=35,92$ (Ss=6,63) ve görsel-uzamsal zekâ $\bar{X}=35,87(\mathrm{Ss}=7,77)$ alanıdır. Öğrencilerin düşük olarak algıladıkları zekâ alanları ise müziksel-ritmik $\bar{X}=29,81$ (Ss=9,26), doğacı $\bar{X}=32,34(S s=9,37)$ ve bedensel-kinestetik zekâ $\bar{X}=32,86$ $(\mathrm{Ss}=9,60)$ alanıdır.

\section{Öğrencilerin Cinsiyetine Göre Çoklu Zekâ Alanlarına İlişkin Algıları}

Araştırmaya katılan öğrencilerin çoklu zekâ alanlarına ilişkin algılarının cinsiyet değişkenine göre istatistiksel olarak anlamlı düzeyde farklılaşıp farklılaşmadığını tespit etmek amacıyla bağımsız gruplarda t testi yapılmıştır. Analiz sonuçları Tablo 3'te verilmiştir.

Tablo 3. Öğrencilerin Çoklu Zekâ Alanlarına Illişkin Algılarının Cinsiyet Değişkenine Göre t Testi Sonuçları

\begin{tabular}{|c|c|c|c|c|c|c|}
\hline Zekâ Alanı & Cinsiyet & $\mathbf{N}$ & $\overline{\mathbf{X}}$ & SS & $t$ & $p$ \\
\hline \multirow[t]{2}{*}{ Sözel-Dilsel } & $\mathrm{K} ı \mathrm{z}$ & 331 & 35,61 & 7,43 & 3,812 & $0,000^{*}$ \\
\hline & Erkek & 325 & 33,33 & 7,87 & & \\
\hline Mantıksal- & Kız & 331 & 37,73 & 8,21 & 2,014 & $0,044 *$ \\
\hline Matematiksel & Erkek & 325 & 36,42 & 8,52 & & \\
\hline Görsel- & $\mathrm{K} ı \mathrm{z}$ & 331 & 37,18 & 7,38 & 4,396 & $0,000 *$ \\
\hline Uzamsal & Erkek & 325 & 34,54 & 7,94 & & \\
\hline Bedensel- & Kız & 331 & 33,13 & 9,59 & 0,739 & 0,460 \\
\hline Kinestetik & Erkek & 325 & 32,58 & 9,63 & & \\
\hline Müziksel- & $\mathrm{K} ı \mathrm{z}$ & 331 & 30,48 & 9,54 & 1,877 & 0,061 \\
\hline Ritmik & Erkek & 325 & 29,13 & 9,93 & & \\
\hline \multirow[t]{2}{*}{ Kişilerarası } & $\mathrm{K} ı \mathrm{z}$ & 331 & 35,74 & 7,02 & $-0,697$ & 0,486 \\
\hline & Erkek & 325 & 36,10 & 6,22 & & \\
\hline \multirow[t]{2}{*}{ İçsel } & Kız & 331 & 34,37 & 7,47 & 3,452 & $0,001 *$ \\
\hline & Erkek & 325 & 32,41 & 7,07 & & \\
\hline \multirow[t]{2}{*}{ Doğacı } & $\mathrm{K} ı \mathrm{z}$ & 331 & 32,84 & 9,59 & 1,389 & 0,165 \\
\hline & Erkek & 325 & 31,83 & 9,12 & & \\
\hline
\end{tabular}

$\left({ }^{*} \mathrm{p}<.05\right.$ anlamlılık düzeyi)

Tablo 3'e göre Çoklu zekâ alanlarına ilişkin algılarında kız ve erkek öğrencilerin sözel-dilsel [t=3,812, $p<.05]$, mantıksal-matematiksel $[t=2,014, p<.05]$, görsel-uzamsal $[t=4,396, p<.05]$ ve içsel zekâ $[t=3,452, p<.05]$ alanlarında istatistiksel olarak anlamlı bir farklılık görülmüştür. Bu farklılık tüm zekâ alanlarında kız öğrenciler lehinedir. Kız öğrencilerin sözel-dilsel ( $\bar{X}=35,61$; Ss=7,43); mantıksal-matematiksel ( $\bar{X}=37,73 ;$ Ss $=8,21)$; görsel-uzamsal $(\bar{X}=37,18$; $S s=7,38$ ) ve içsel zekâ ( $\bar{X}=34,37 ; S s=7,47$ ) alanlarına ait algıları erkek öğrencilerinkinden daha yüksektir. 


\section{Öğrencilerin iMDÖP’te Yer Alan Alana Özgü Problem Çözme Becerileri}

Öğrencilerin IMDÖP'te yer alan alana özgü problem çözme becerilerine ilişkin hesaplanan betimsel istatistikler Tablo 4'te verilmiştir.

Tablo 4. Öğrencilerin iMDÖP’te Yer Alan Alana Özgü Problem Çözme Becerilerine ilişkin Betimsel İstatistik Sonuçları

\begin{tabular}{ccccccc}
\hline Test Adı & MaddeSayısı & N & Minimum & Maximum & $\overline{\mathbf{X}}$ & SS \\
\hline $\begin{array}{c}\text { Problem } \\
\text { Çözme } \\
\text { Becerisi }\end{array}$ & 30 & 656 & 6,00 & 30,00 & 20,50 & 6,47 \\
\hline
\end{tabular}

Tablo 4 incelendiğinde öğrencilerin problem çözme beceri ortalamasının $\bar{X}=20,50$ olduğu bulunmuştur. Öğrencilerin Problem çözme becerileri puanlarının minimum $\bar{X}=6,00$ ve maximum $\bar{X}=30,00$ olduğu belirlenmiştir. Problem çözme beceri testinde 11-20 puan arası orta düzey başarı için sınır olarak kabul edilmiştir. Öğrencilerin problem çözme beceri testinin ortalaması $\bar{X}=20,50$ olduğu için öğrenciler problem çözme beceri testinde orta düzeyde başarılı olmuştur.

\section{Öğrencilerin Cinsiyetine Göre iMDÖP’te Yer Alan Alana Özgü Problem Çözme Becerileri}

Öğrencilerin IMDÖP'te yer alan alana özgü problem çözme becerilerinin cinsiyet değişkenine göre istatistiksel olarak anlamlı düzeyde farklılaşıp farklılaşmadığını tespit etmek amacıyla bağımsız gruplarda t testi yapılmıştır. Analiz sonuçları Tablo 5'te verilmiştir.

Tablo 5. Öğrencilerin iMDÖP’te Yer Alan Alana Özgü Problem Çözme Becerilerinin Cinsiyet Değişkenine Göre t Testi Sonuçları

\begin{tabular}{cllllll}
\hline & Cinsiyet & $\mathbf{N}$ & $\overline{\mathbf{X}}$ & $\mathbf{S S}$ & $\mathbf{t}$ & $\mathbf{p}$ \\
\cline { 2 - 6 } Problem Çözme & Kız & 331 & 21,01 & 6,29 & $2,026^{*}$ & $0,043^{*}$ \\
Becerisi & Erkek & 325 & 19,99 & 6,62 & & \\
\hline
\end{tabular}

$\left({ }^{*} \mathrm{p}<.05\right.$ anlamlılık düzeyi)

Tablo 5'e göre problem çözme beceri testi ortalamaları cinsiyet değişkenine göre istatistiksel olarak anlamlı farklılık göstermektedir [t=2,026; $p<.05]$. Problem çözme beceri testinde kız öğrencilerin puan ortalamaları $\bar{X}=21,01$ (Ss=6,29); erkek öğrencilerin ise $\bar{X}=19,99(S s=6,62)$ olarak bulunmuştur. Yani kız öğrencilerin problem çözme beceri ortalamaları erkek öğrencilerin problem çözme beceri ortalamalarından yüksektir. Kız öğrenciler problem çözme testinde erkek öğrencilerden daha başarıııdır.

Öğrencilerin Çoklu Zekâ Alanları ile Matematik Öğretim Programında Yer Alan Alana Özgü Problem Çözme Becerileri Arasındaki iliş̧ki

Araştırmaya katılan öğrencilerin çoklu zekâ alanlarına ilişkin algıları ile ilköğretim matematik dersi öğretim programında yer alan alana özgü problem çözme becerileri arasındaki ilişkiyi incelemek için yapılan korelasyon analizi sonuçları Tablo 6'da verilmiştir.

Tablo 6. Öğrencilerin Çoklu Zekâ Alanları İle Matematik Öğretim Programında Yer Alan Alana Özgü Problem Çözme Becerileri Arasındaki Korelasyon Analizi Sonuçları

\begin{tabular}{lcc}
\hline Zekâ Alanları & \multicolumn{2}{c}{ Problem Çözme Becerisi } \\
\cline { 2 - 3 } & $\mathbf{r}$ & $\mathbf{p}$ \\
\hline Sözel-Dilsel & 0,45 & $0,000^{*}$ \\
Mantıksal-Matematiksel & 0,63 & $0,000^{*}$ \\
Görsel-Uzamsal & 0,37 & $0,000^{*}$ \\
Bedensel-Kinestetik & 0,06 & 0,101 \\
Müziksel-Ritmik & $-0,36$ & $0,000^{*}$ \\
Kişilerarası & 0,06 & 0,153 \\
İçsel & 0,05 & 0,184 \\
Doğacı & $-0,03$ & 0,517 \\
\hline
\end{tabular}

( $N=656, * p<.05$ anlamlılık düzeyi) 
Tablo 6 incelendiğinde 8. sınıf öğrencilerinin problem çözme becerileri ile sözel-dilsel zekâ alanına ilişkin algıları arasında orta düzeyde $(r=0,45)$ ve pozitif yönde bir ilişki bulunmuştur. Bu da öğrencilerin sözel-dilsel zekâ alanına ait algıları arttıkça problem çözme becerilerinin arttığını göstermektedir. Öğrencilerin sözel-dilsel zekâ alanının gelişmesi problem çözme becerilerini geliştirmektedir. 8. sınıf öğrencilerinin problem çözme becerileri ile mantıksalmatematiksel zekâ alanına ilişkin algıları arasında orta düzeyde $(r=0,63)$ ve pozitif yönde bir ilişki bulunmuştur. Öğrencilerin mantıksal-matematiksel zekâ alanına ait algıları arttıkça problem çözme becerileri artmaktadır. Öğrencilerin mantıksal-matematiksel zekâlarının gelişmesi problem çözme becerilerini olumlu etkilemektedir. 8. sınıf öğrencilerinin problem çözme becerileri ile görsel-uzamsal zekâ alanına ilişkin algıları arasında orta düzeyde $(r=0,37)$ ve pozitif yönde bir ilişki bulunmuştur. Öğrencilerin görsel-uzamsal zekâ alanına ait algıları arttıkça problem çözme becerileri artmaktadır. Yani öğrencilerin görsel-uzamsal zekâlarının gelişmesi problem çözme becerilerini olumlu etkilemektedir. 8. sınıf öğrencilerinin problem çözme becerileri ile müziksel-ritmik zekâ alanına ilişkin algıları arasında orta düzeyde $(r=-0,36)$ ve negatif yönde bir ilişki bulunmuştur. Buna göre öğrencilerin müziksel-ritmik zekâ alanına ait algıları artııkça problem çözme becerileri azalmaktadır. Yani öğrencilerin müziksel-ritmik zekâ alanına ilişkin algılarının artması problem çözme becerilerini olumsuz etkilemektedir.

Tablo 6 incelendiğinde 8. sınıf öğrencilerinin problem çözme becerileri ile bedensel-kinestetik, kişilerarası, içsel ve doğacı zekâ alanlarına ait algıları arasında istatistiksel olarak anlamlı bir ilişki bulunmamıştır ( $p>.05)$.

\section{iMDÖP’te Yer Alan Alana Özgü Problem Çözme Becerisinin Yordanmasına ilişskin Bulgular}

8. sınıf öğrencilerinin çoklu zekâ alanlarına ilişkin algılarının ilköğretim matematik dersi öğretim programında yer alan alana özgü problem çözme becerisini yordamasına ilişkin yapılan çoklu doğrusal regresyon analizi sonuçları Tablo 7'de verilmiştir.

Tablo 7. iMDÖP’te Yer Alan Alana Özgü Problem Çözme Becerisinin Yordanmasına İlişkin Standart Çoklu Doğrusal Regresyon Analizi Sonuçları

\begin{tabular}{lccccccc}
\hline Değişkenler & $\mathbf{B}$ & $\begin{array}{c}\text { Standart } \\
\text { Hata }\end{array}$ & $\boldsymbol{\beta}$ & $\mathbf{t}$ & $\mathbf{p}$ & $\begin{array}{c}\text { Ikili } \\
\mathbf{r}\end{array}$ & $\begin{array}{c}\text { Kısmi } \\
\mathbf{R}\end{array}$ \\
\hline Sabit & 9,311 & 1,573 & & 5,920 &, 000 & & \\
Sözel-Dilsel &, 057 &, 037 & 068 & 1,544 &, 123 &, 452 &, 061 \\
$\begin{array}{l}\text { Mantıksal- } \\
\begin{array}{l}\text { Matematiksel } \\
\text { Görsel-Uzamsal }\end{array}\end{array}$ &, 438 &, 033 & 567 & 13,235 &, $000^{*}$ &, 630 &, 462 \\
Bedensel-Kinestetik &,- 018 &, 035 &, 022 &,- 523 &, 601 &, 374 &,- 021 \\
Müziksel-Ritmik &,- 023 &, 021 &, 034 & $-1,113$ &, 266 &, 064 &,- 044 \\
Kişilerarası &, 023 &, 170 & $-5,197$ &, $000 *$ &,- 364 &,- 200 \\
Içsel &, 004 &, 031 &, 005 &,- 146 &, 884 &, 056 &,- 006 \\
Doğacı &,- 015 &, 029 &, 017 &,- 532 &, 595 &, 052 &,- 021 \\
\hline
\end{tabular}

$R=0.664, R^{2}=0.440, \Delta R^{2}=, 434, p=.000, F_{(8,647)}=63.653, p<.01$

Varyans analizi sonucunda, çoklu regresyon modeli anlamlı bulunmuştur; yordayıcılardan en az bir tanesi problem çözme becerisi üzerinde tahmin oluşturmak için kullanışlıdır $(p<.05)$. Çoklu zekâ alanları birlikte iMDÖP'te yer alan alana özgü problem çözme becerisine ilişkin varyansın \%44'ünü açıklamaktadır. Mantıksal-matematiksel zekâ iMDÖP'te yer alan alana özgü problem çözme becerisi üzerinde anlamlı pozitif bir yordayıcıdır $(p<.05)$. Mantıksalmatematiksel zekâ alanındaki bir birimlik artış iMDÖP'te yer alan alana özgü problem çözme becerisinde 0,438'lik artışa yol açmaktadır. Müziksel-ritmik zekâ iMDÖP'te yer alan alana özgü problem çözme becerisi üzerinde anlamlı negatif bir yordayıcıdır ( $p<.05)$. Müziksel-ritmik zekâ alanındaki bir birimlik artış IMDÖP'te yer alan alana özgü problem çözme becerisinde $-0,119^{\prime}$ luk düşüşe yol açmaktadır. Sözel-dilsel, görsel-uzamsal, bedensel-kinestetik, kişilerarası, içsel ve doğacı zekâ alanları iMDÖP'te yer alan alana özgü problem çözme becerisi üzerinde anlamlı bir yordayıcı 
değildir ( $p>05)$. Standardize edilmiş regresyon katsayısına $(\beta)$ göre, mantıksal-matematiksel zekâ alanı alana özgü problem çözme becerisinin en önemli yordayıcısıdır $(\beta=0,567)$.

\section{Sonuç ve Öneriler}

$\mathrm{Bu}$ araştırma sonucunda öğrencilerin Çoklu Zekâ Envanterine verdikleri yanıtlara göre en yüksek olarak algıladıkları zekâ alanı mantıksal-matematiksel zekâdır. Bu zekâ alanını kişilerarası ve görsel-uzamsal zekâ alanları izlemektedir. Öğrencilerin en düşük olarak algıladıkları zekâ alanı ise müziksel-ritmik zekâdır. Bu zekâ alanını doğacı ve bedensel-kinestetik zekâ alanları izlemektedir. Gürses'in (2011) ortaokul öğrencileri üzerinde yaptığı çalışma bu araştırmanın sonucunu desteklemektedir. Gürses'in (2011) çalışmasında; öğrencilerin en yüksek algıladıkları zekâ alanları mantıksal-matematiksel ve görsel-uzamsal zekâ alanı; en düşük algıladıkları ise müziksel-ritmik zekâ alanıdır. Bulut'un (2003) 5. sınıf öğrencileri üzerinde yaptığı çalışma ile mevcut araştırma sonuçları benzerlik göstermektedir. Bulut'un (2003) çalışmasında öğrencilerin en yüksek algıladıkları zekâ alanları mantıksal-matematiksel, kişilerarası ve görsel-uzamsal zekâ alanları, en düşük algıladıkları zekâ alanı ise bedensel-kinestetik zekâ alanıdır. Erman'ın (2003) 4. sınıf öğrencileri üzerinde yaptığı çalışmada öğrencilerin baskın olan zekâ alanları kişilerarası, mantıksalmatematiksel ve görsel-uzamsal zekâdır. Bu araştırma sonucu ile mevcut araştırma sonuçları benzerlik göstermektedir. İpekli'nin (2013) 10. sınıf öğrencileri üzerinde yaptığı çalışmada; öğrencilerin en yüksek algıladıkları zekâ alanı görsel-uzamsal, bedensel-kinestetik ve kişilerarası, en düşük olarak algıladıkları zekâ alanı ise müzikselritmik zekâ alanıdır. Görsel-uzamsal, kişilerarası ve müziksel-ritmik zekâ alanları bakımından sonuçlar bu araştırma ile benzerlik göstermektedir. Bedensel-kinestetik zekâ alanında farklı sonuç olmasının nedeni, araştırma yapılan öğrenci grubunun farklı eğitim seviyesinde bulunmasından kaynaklanıyor olabilir. Kozağaç'ın (2015) üniversite öğrencileri üzerinde yaptığı çalışmada öğrencilerin en yüksek puan ortalamaları mantıksal-matematiksel, kişilerarası, görsel-uzamsal ve bedensel-kinestetik zekâ alanına aittir. Mantıksal-matematiksel, görsel-uzamsal, kişilerarası zekâ alanlarına ait sonuçlar bu araştırma ile örtüşmektedir. Öğrencilerin ailelerinde sağlıklı bir iletişimin olması, düşüncelere saygı duyulması ve aile fertlerine değer verilmesi ya da öğrencilerin okulda arkadaşlarıla oyun oynamaları, sosyal faaliyetler ve grup çalışmalarında, etkinliklerde bir arada bulunup iletişim halinde olmaları kişilerarası zekâ alanına ilişkin algılarının yüksek olmasında etkili olabilir. Temiz'e (2007) göre öğrencilerin farklı ortamlara uyum sağlama, sözlü ve sözsüz iletişim kurma, grup içerisinde ortak hareket etme, düşüncelerini belirtme, organize olma vb. davranışları kişilerarası zekâ alanına ait algılarının yüksek olduğunun göstergesidir. Öğrencilerde ilköğretimin ilk yıllarından itibaren matematiğin önemli bir ders olduğu düşüncesi, bu düşünceyle okulda ve ailede matematiğe önem verilmesi mantıksal-matematiksel zekâ alanına ilişkin algılarının yüksek olmasında etkili olabilir (Dursun ve Dede, 2004). Öğrencilerin günlük hayatta karşılaştığı problemleri çözerken kurduğu mantıksal çıkarımlar ve 8. sınıfta uygulanan "Liselere Geçiş Sınavı"nın değerlendirilmesinde matematiğin önemli katkısının olması öğrencilerin mantıksal-matematiksel zekâ alanına ilişkin algılarının yüksek olmasında etkili olmuş olabilir. Mantıksalmatematiksel zekâ alanına ait algıları yüksek olan öğrenciler akıl yürütme, hesap yapma ve problem çözümlerinde mantıksal çıkarımlarda bulunma özelliklerine sahiptirler (Demirel vd., 2006; Talu, 1999). illköğretim seviyesindeki öğrencilerin renkli görsellere ve materyallere ilgili olmaları görsel-uzamsal zekâ alanına ilişkin algılarının yüksek olmasında etkili olabilir. Görsel-uzamsal zekâ alanına ilişkin algıları yüksek olan öğrenciler öğrendiklerini görsel şekillerle ifade etmeyi tercih ederler. Renklere, sembollere, imajlara ve dokulara dikkat ederler (Selçuk vd., 2004). Bu çalışmada; öğrencilerin müziksel-ritmik zekâ alanına ilişkin algılarının düşük olmasında, öğrencilerin bu zekâ alanını geliştirecekleri derslerin ortaokul müfredatında az olması veya ders saatlerinin az olması etkili olabilir. Öğrencilerin "Liselere Geçiş Sınavı"nda yer alan derslere yönelik daha fazla eğitim faaliyetinde bulunmaları, tercih edecekleri ortaöğretim kurumunun ve gelecekte sahip olmak istedikleri mesleklerin müziksel-ritmik zekâ alanı ile ilgili olmayışı ve ailenin tutumu da müziksel-ritmik zekâ alanına ilişkin algılarının düşük olmasında etkili olabilir. Oysa eğitim ortamında öğrencilerin sadece matematiksel ve sözel zekâsı değil diğer zekâ alanlarının da geliştirilmesi gerekir. Bunun için derslerde öğretmenler öğrencilere müzik ya da şarkı yoluyla da öğretim yaparak ya da rol yapma, drama gibi teknikleri matematiksel problemlere uyarlayarak dersleri daha ilgi çekici hale getirebilir. Yani öğretmenler tüm zekâ alanlarını dikkate alarak ders etkinliklerini ve materyalleri hazırlamalıdır.

Araştırmaya katılan öğrencilerin sözel-dilsel, mantıksal-matematiksel, görsel-uzamsal ve içsel zekâ düzeylerine ilişkin algıları cinsiyet değişkenine göre anlamlı düzeyde birbirinden farklılaşmıştır. Bu farklılık kız öğrenciler lehinedir. Kız öğrencilerin sözel-dilsel, mantıksal-matematiksel, görsel-uzamsal ve içsel zekâ düzeylerine ilişkin algıları erkek öğrencilere göre daha yüksek düzeydedir. Bu araştırmanın sonucunu, Yenilmez ve Çalışkan'ın (2011) çalışması desteklemektedir. Yenilmez ve Çalışkan'ın (2011) ortaokul öğrencileri üzerinde yaptıkları çalışmada sözel-dilsel, görsel-uzamsal ve içsel zekâ alanlarında kız öğrenciler lehine anlamlı farkılık bulunmuştur. Çamurcu Nuhoğlu'nun (2007) ortaokul öğrencilerinin zekâ alanlarını incelediği çalışmada; görsel-uzamsal, sözel-dilsel, kişilerarası, müziksel- 
ritmik zekâ alanında kız öğrenciler lehine anlamlı bir farklılık bulmuştur. Göde ve Erturan'ın (2008) 4. sınıf öğrencileri üzerinde yaptıkları çalışmada kız ve erkek öğrencilerin bedensel-kinestetik zekâ algılarının farklılaşmadığı sonucuna ulaşılmıştır. Göde ve Erturan'ın (2008)’ çalışması ile yapılan bu araştırma bedensel-kinestetik zekâ alanı yönünden örtüşmektedir. Yaz'ın (2013) üniversite öğrencileri üzerinde yaptığı çalışmada; kız öğrencilerin içsel zekâ alanına ilişkin algıları; erkek öğrencilere göre daha yüksektir. Kabataş'ın (2006) 10. sınıf öğrencileri ile yaptığı çalışma sonucu mevcut araştırma sonuçlarını desteklemektedir. Kabataş’ın (2006) çalışmasında sözel-dilsel, görsel-uzamsal ve içsel zekâ alanlarında kız öğrenciler lehine anlamlı düzeyde farklılaşma bulunmuştur. Loori'nin (2005) üniversite öğrencilerinin çoklu zekâ alanlarının cinsiyetlerine göre farklılık gösterip göstermediğini araştırdığı çalışmasında, mantıksal-matematiksel ve içsel zekâ alanında anlamlı farklılık bulunmuştur. Mantıksal-matematiksel zekâ alanında bu çalışmadan farklı olarak erkekler lehine, içsel zekâ alanında bu araştırmada olduğu gibi kızlar lehine anlamlı farklılık bulunmuştur. Sözel-dilsel, görsel-uzamsal, müziksel-ritmik, bedensel-kinestetik zekâ alanlarında cinsiyete göre farklılaşma bulunmamıştır. Bu yönüyle yapılan bu araştırma sonuçları ile benzerlik göstermektedir. Mantıksalmatematiksel zekâ alanında bu çalışmadan farklı sonuç olmasının nedeni araştırma yapılan grubun farklı öğretim seviyesinde ve farklı kültürde olması olabilir. Tekin ve Güllü’nün (2009) ortaöğretim öğrencileri ile yaptıkları çalışmada sözel-dilsel, görsel-uzamsal, müziksel-ritmik, kişilerarası ve içsel zekâ alanlarına ait algıları arasında kızlar lehine anlamlı farklılık bulunmuştur. Tekin ve Güllü’nün (2009) çalışması; sözel-dilsel, görsel-uzamsal, içsel zekâ alanları açısından yapılan bu araştırmayı desteklemektedir. Araştırmaya katılan kız öğrencilerin ergenlik döneminde müzik dinlemeye ve şarkı sözlerine daha ilgili olmaları, insanlarla daha fazla bir arada olma istekleri, müziksel-ritmik ve kişilerarası zekâ alanlarında yapılan araştırmadan farklı sonuç bulunmasının sebebi olabilir (Kuzgun, 2004). Nasser, Singhal ve Abouchedid (2008) tarafından Lübnanlı ve Hindistanlı üniversite öğrencileri üzerinde yapılan çalışmada, her iki ülkede de sözel-dilsel zekâ alanında kızlar lehine anlamlı farklılık bulunmuştur. Aynı çalışmada Lübnanlı öğrencilerin mantıksal-matematiksel, kişilerarası ve içsel, bedensel-kinestetik zekâ alanları cinsiyet değişkenlerine göre farklılaşmıştır. Kız öğrencilerin içsel zekâ alanına ait algıları erkek öğrencilerden yüksek bulunmuştur. Bu yönüyle yapılan bu araştırmanın bulgularını desteklemektedir. Mantıksal-matematiksel, kişilerarası ve bedensel-kinestetik zekâ alanları yönünden bu araştırmadan farklılaşmaktadır. Bunun sebebi kültürel farklılıklar ve ülkelerin eğitim programlarındaki farklılıklardan ya da ülkede kız ve erkek öğrencilerin eğitimine verilen önemden kaynaklanabilir. Terman ve Tyler'a (1963) göre kızlar erkeklere göre daha erken yaşta konuşmaya başlamakta, sözcükleri kullanırken daha dikkatli olmaktadırlar (Akt. Kuzgun, 2004). Bu araştırmada sözel-dilsel zekâ alanında kız öğrenciler lehine anlamlı bir farklılık çıkmasının nedeni kız öğrencilerin kendini ifade edebilme yeteneğinin, etkin dinleme ve konuşma becerilerinin daha iyi olduğundan kaynaklanabilir. Kız öğrencilerin mantıksal-matematiksel zekâ alanına ait algılarının erkek öğrencilerden daha yüksek çıkmasında kız öğrencilerin eğitim-öğretim etkinliklerine daha fazla katılım sağlamaları ve kızların eğitim-öğretim faaliyetlerine (kurs, sergi, proje vb.) daha fazla ilgili olmalarından kaynaklanıyor olabilir. Kız öğrencilerin güzellik ve estetiğe karşı ilgili olmaları, görsellerin ayrıntılarına dikkat etmeleri görsel-uzamsal zekâ alanına ait algılarının daha yüksek çıkmasında etkili olmuş olabilir. Kızların çocukluk döneminden itibaren göz el koordinasyonu gerektiren işlerde bulunmaları bu durum üzerinde etkili olabilir (Kuzgun, 2004). Kız öğrencilerin erkek öğrencilerden daha duygusal olmaları, olayları detaylı bir şekilde incelemeleri içsel zekâ alanına ilişkin algı düzeylerinin erkek öğrencilerin algı düzeylerinden yüksek olmasında etkili olabilir (Şahin, 2007). Bu sonuçlar doğrultusunda erkek öğrencilerin düşük çıkan zekâ alanlarındaki becerilerini artırmak amacıyla erkek öğrencilere sınıf ortamında daha fazla görev ve sorumluluk verilmeli; derste kendilerini daha fazla ifade edeceği; göz el koordinasyonu gerektiren işlerde daha fazla sorumluluk alacağı ortamlar yaratılmalıdır.

Öğrenciler IMDÖP'te yer alan alana özgü problem çözme becerilerinde orta düzeyde başarılı olmuştur. Araştırmaya katılan öğrencilerin, 8. Sınıf düzeyinde oldukları için “Liselere Geçiş Sınavı”na hazırlanmaları ve ilköğretimden itibaren matematik dersinde problem çözmeye yönelik etkinliklerde bulunmaları bu ortalamada etkili olabilir. Öğrencilerin tercih edeceği ortaöğretim kurumunun belirlenmesinde "Liselere Geçiş Sınavı"nın yüksek düzeyde etkisi bulunmaktadır. "Liselere Geçiş Sınavı”nda matematik dersinin katsayısının önemli bir katkısının olması öğrencilerin matematiksel problemlerin çözümleri için farklı stratejiler geliştirmelerine sebep olabilir. Bununla birlikte öğretmenler problem çözme becerisini geliştirmek için Seçmeli Matematik Uygulamaları ve Seçmeli Zekâ Oyunları derslerinde problem kurma ve çözme etkinlikleri düzenlemelidir. Öğrencilere satranç, mangala, surakarta, futoşhiki, triominos vb. gibi problem çözme ve karar verme becerilerini geliştiren strateji oyunları oynatılmalıdır.

Araştırmaya katılan öğrencilerin iMDÖP'te yer alan alana özgü problem çözme becerilerinde cinsiyete göre anlamlı düzeyde farklılık vardır. Bu farklılık kızlar lehinedir. Kız öğrencilerin iMDÖP'te yer alan alana özgü problem çözme beceri ortalamaları, erkek öğrencilere göre yüksektir. Carr, Jessup ve Fuller (1999) tarafından ilköğretim birinci sınıf öğrencileriyle yapılan çalışmada kız öğrencilerin problem çözme performanslarının erkek öğrencilerden daha iyi olduğu bulunmuştur. Gallagher, De Lisi, Holst, McGillicuddy-De Lisi, Morely ve Cahalan (2000) tarafından öğrenciler 
üzerinde problem çözme becerilerine yönelik yapılan çalışmada cinsiyete göre farklılık bulunmamıştır. Bunun sebebi, kültürel farklılıklardan kaynaklanabilir. Kız öğrencilerin matematik dersinde proje ödevi hazırlamaya daha istekli olmaları, destekleme ve yetiştirme kurslarına katılım oranlarının daha yüksek olması bu durumun nedeni olabilir. Ayrıca günümüzde kızların okuma oranının büyük ölçüde artması ve meslek sahibi olmalarında matematik dersinin önemli rol oynaması iMDÖP'te yer alan alana özgü problem çözme becerilerinde erkek öğrencilerden daha başarılı olmalarında etkili olabilir. Kız öğrencilerin yanında erkek öğrencilerin de problem çözme becerisinin artması için erkek öğrenciler derslerde öğretmen tarafından problem üzerinde daha fazla düşünmeye ve çözüm üretmeye teşvik edilmelidir.

Araştırmaya katılan öğrencilerin IMDÖP'te yer alan alana özgü problem çözme becerileri ile sözel-dilsel, mantıksal-matematiksel ve görsel-uzamsal zekâ alanlarına ait algıları arasında pozitif yönde ve orta düzeyde ilişki; müziksel-ritmik zekâ alanına ait algıları arasında ise negatif yönde ve orta düzeyde bir ilişki vardır. Problemi anlama Polya'nın problem çözme sürecinin en önemli aşamasıdır. Problemi anlamayan öğrencinin problemin çözümüyle ilgili strateji seçmesi, plan yapması ve uygulaması mümkün olmamaktadır. Öğrencilerin sözel-dilsel zekâ alanına ait algıları ile problem çözme becerileri arasında pozitif yönlü bir ilişkinin olmasında öğrencilerin okuduğunu anlama, problemi kendi cümleleriyle ifade edebilme, problemi bir başkasına açıklayabilme ve verilen probleme benzer problem yazabilme vb. becerilerinin iyi düzeyde olması etkili olabilir. Bu bulgudan hareketle matematik öğretmenlerine, öğrencilerin problem çözme becerilerini artırmak için sözel-dilsel zekâ alanına yönelik etkinlikler yapmaları önerilebilir. Öğretmenler öğrencilerinden, problemi başka biçimde ifade etmelerini, benzer problem kurmalarını ve problemi açıklamalarını istemelidir. Yine öğretmen öğrencilerinden, matematiğin nerede ve nasıl ortaya çıktığııın araştırılmasını, sunulmasını ve tartışılmasını isteyebilir. Öğrencilerini matematiksel formüllerin nasıl oluştuğu ile ilgili kitap okumaları için yönlendirebilir. Öğrencilere çözmeleri istenen problemle ilgili olarak düşüncelerini yazdırıp bunları inceleyebilir. Bu yazılar, onların problemi nasıl anladıkları konusunda öğretmene önemli ipuçları verecektir.

Öğrencilerin mantıksal-matematiksel zekâ alanı ile matematiksel problem çözme becerileri doğrudan ilişkilidir. Öğrenciler matematiksel problemleri çözerken mantıksal-matematiksel zekâ alanına yönelik etkinliklerde bulunmaktadırlar. Schoenfeld'e (1985) göre öğrenciler derinlemesine bilmedikleri konularda matematiksel bilgiyi problem çözme sürecinde kullanmakta sorun yaşamaktadır. Öğrencilerin problem oluşturmaları, problem çözmeleri matematik dersinde konulara ait bilgisini göstermektedir. Mantıksal-matematiksel zekâ alanına ait algıları yüksek olan öğrenciler, problem çözme sürecinde akıl yürütme, mantıksal çıkarımda bulunma, sistematik liste oluşturma vb. stratejileri tercih edebilirler. Matematik dersindeki akıl yürütme, tahmin ve kontrol, denklem kurma, sistematik liste oluşturma vb. stratejiler mantıksal-matematiksel zekâ ile doğrudan ilgilidir. Bu nedenle sınıfta öğrencilerin problem çözme sürecinde farklı stratejileri kullanacağı rutin olmayan problemlere yer verilmelidir. Öğretmenler öğrencilerinden problem kurmalarını ve farklı stratejiler kullanarak çözmelerini istemelidir. Matematik dersinde öğrenciler, problem çözme sürecinde özgün stratejiler geliştirebilirler. Öğrencilerin ezberden uzak, kavramsal ve işlemsel bilgiyi bir arada kullandığı ve bilgileri arasında bağlantı kurabildiği problemlere yer verilmelidir. Ayrıca ders kitaplarında aritmetik problemlerin yanında öğrencilerin farklı stratejileri kullanabilecekleri (bir problemi başka bir biçimde ifade etme, örüntü bulma, geriye doğru çalışma, problemi basitleştirme, varsayımları kullanma vb.) problemlere yer verilmelidir.

Araştırmaya katılan öğrencilerin IMDÖP'te yer alan alana özgü problem çözme becerileri ile görsel-uzamsal zekâ alanına ait algıları arasında pozitif yönde ilişki bulunmuştur. Bunun nedeni matematik problemlerini çözme sürecinde öğrencilerin şekil ve şema oluşturmaları, zihinlerinde çözüm için canlandırdıklarını çizim yaparak somutlaştırmaya çalışmaları etkili olabilir. Öğrencilerin Seçmeli Zekâ Oyunları dersinde yap-boz, su doku, resfebe vb. şeklindeki çalışmaları da bu durumun sebebi olabilir. Öğretmenler öğrencilerin matematiksel problem çözme becerilerini artırmak için görsel-uzamsal zekâ alanına yönelik etkinlik düzenleyebilir. Problemlerin çözümlerini görsel-uzamsal zekâ alanını destekleyecek şekilde Cabri II, Cabri 3D, GeoGebra vb. yazılımları kullanarak gerçekleştirebilir. Ek olarak simetri aynası, sayı pulları, yüzlük bloklar, geometri tahtası, üç boyutlu geometrik cisimler vb. materyaller problem çözümlerinde kullanılmalıdır.

Bu araştırmada çoklu zekâ alanlarının birlikte, problem çözme becerisindeki toplam varyansın \% $44^{\prime}$ ünü açıkladığı bulunmuştur. iMDÖP'te yer alan alana özgü problem çözme becerisi için mantıksal-matematiksel zekâ orta düzeyde ve pozitif anlamlı yordayıcı, müziksel-ritmik zekâ düşük düzeyde ve negatif anlamlı yordayıcı olarak bulunmuştur. Dursun ve Dede (2004) ilköğretim matematik öğretmenlerinin görüşlerini aldıkları çalışmalarında öğrencilerin matematik başarısında mantıksal-matematiksel zekâlarının önemli bir faktör olduğunu belirtmişlerdir. iMDÖP'te yer alan alana özgü problem çözme becerisi için müziksel-ritmik zekânın düşük düzeyde ve negatif anlamlı yordayıcı çıkmasında öğrencilerin matematiksel problem çözümlerinde müziksel-ritmik zekâ alanına yönelik bir etkinlikte 
bulunmamaları ve matematik derslerinde bu alana yönelik çalışmalar da olmaması etkili olabilir. Matematik derslerinde ya da Seçmeli Matematik derslerindeki etkinliklerde müziksek-ritmik zekâ alanın dikkate alınıp bu zekâ alanına uygun etkinliklerin hazırlanması hem öğrencilerin müziksel-ritmik zekâsını geliştirir hem de matematik dersini ve problem çözme sürecini öğrenciler için daha eğlenceli ve etkili hale getirebilir.

Yukarıdaki sonuç ve önerilere ek olarak bu konuda çalışmak isteyen araştırmacılar için şunlar önerilebilir: Benzer bir araştırma Bilim ve Sanat Merkezi'nde öğrenim gören üstün zekâlı olduğu kabul edilen öğrenciler üzerinde yapılmalıdır. Problem çözümlerinde farklı stratejileri bir arada kullanan öğrenciler ile tek strateji kullanan öğrenciler arasındaki farklılıklar araştıılabilir. Polya'nın problem çözme adımlarından "Planın uygulanması aşaması" ile problem çözme stratejileri arasındaki ilişki incelenebilir. Ayrıca öğrencilerin problem çözerken kullandıkları stratejiler ve kullanma nedenleri nicel araçların yanında görüşme, gözlem gibi nitel araştırma yöntemleri de kullanılarak araştırılabilir.

\section{Kaynakça}

Azar, A. , Presley, A. I., Balkaya, Ö. (2006). Çoklu zekâ kuramına dayalı öğretimin öğrencilerin başarı, tutum, hatırlama ve bilişsel süreç becerisine etkisi. Hacettepe Üniversitesi Eğitim Fakültesi Dergisi, 30, 45-54.

Bayazit, i. ve Aksoy, Y. (2009). Matematiksel öğrenim ve öğretimi. E, Bingölbali ve M, F, Özmantar. (Eds.). Matematiksel Zorluklar ve Çözüm Önerileri. Ankara: Pegem Akademi.

Baykul, Y. ve Güzeller Oktay, C. (2014). Sosyal bilimler için istatistik. (2. Baskı). Ankara: Pegem Akademi.

Bulut, i. (2003). Çocuklara yabancı dil olarak ingilizce öğretimi ve çoklu zekâ teorisi. Yayımlanmamış Yüksek Lisans Tezi. İstanbul Üniversitesi Sosyal Bilimler Enstitüsü, İstanbul.

Büyüköztürk, Ş. (2014). Sosyal bilimler için veri analizi el kitabı. Ankara: Pegem Akademi.

Büyüköztürk, Ş., Çakmak Kılıç, E., Akgün, E. Ö., Karadeniz, Ş. ve Demirel, F. (2014). Bilimsel araştırma yöntemleri. (Geliştirilmiş 17. Baskı). Ankara: Pegem Akademi.

Büyüköztürk, Ş., Köklü, N. Ve Çokluk, Ö. (2007). Sosyal bilimler için istatistik (2. Baskı), Ankara, Pegem Akademi.

Carr, M., Jessup, L. D. ve Fuller, D. (1999). Gender differences in first-grade mathematics strategy use: Parent and teacher contributions, Journal for Research in Mathematics Education, 30 (1), 20-46.

Çamurcu Nuhoğlu, S. (2007). illköğretim ikinci kademe öğrencilerinin çoklu zekâ alanlarına yönelik dağılım düzeylerinin tespit edilmesi. Yayımlanmamış Yüksek Lisans Tezi. Karadeniz Teknik Üniversitesi, Sosyal Bilimler Enstitüsü, Trabzon.

Demir, B. (2016). Türkçe dersi çalışma kitaplarındaki etkinliklerin çoklu zekâ kuramı bakımından incelenmesi. Yayımlanmamış Yüksek Lisans Tezi, Ahi Evran Üniversitesi Sosyal Bilimler Enstitüsü, Kırşehir.

Demirel, Ö., Başbay, A. ve Erdem, E. (2006). Eğitimde çoklu zekâ kuram ve uygulama. Ankara: Pegem A Yayıncılık.

Dursun, Ş. ve Dede, Y. (2004). Öğrencilerin matematikte başarısını etkileyen faktörler: matematik öğretmenlerinin görüşleri bakımından, Gazi Eğitim Fakültesi Dergisi, 24(2), 217-230.

Erden, M. (1986). İlkokulların birinci devresine devam eden öğrencilerin dört işleme dayalı problemleri çözerken gösterdikleri davranışlar. Hacettepe Üniversitesi Eğitim Fakültesi Dergisi, 1, 105-113.

Erman, A. (2003). Illköğretim IV. sınıf öğrencilerinin çoklu zekâ türlerindeki dağılım ve düzey ölçümlerinin müziksel zekâ düzeyleriyle karşılaştırmalı incelenmesi. Yayımlanmamış Yüksek Lisans Tezi, Gazi Üniversitesi Eğitim Bilimleri Enstitüsü, Ankara.

Gallagher, M.A., De Lisi, R., Holst, C. P., McGillicuddy-De Lisi, M.V.A, Morely, M. Ve Cahalan, C. (2000). Gender differences in advenced mathematical problem solving, Journal of Experimental Child Psychology, 75, 165-190.

Gardner, H. (2004). Zihin çerçeveleri çoklu zekâ kuramı. (Çev. E. Kılıç). İstanbul: Alfa Yayınları. (Eserin Orijinali 1983’te yayımlandı).

Göde, O. Ve Erturan, G.A. (2008). İlköğretim dördüncü sınıf öğrencilerinin bedensel-kinestetik zekâ erişilerinin cinsiyet ve spor yapma durumlarına göre karşılaştırılması. Hacettepe Spor Bilimleri Dergisi, 19 (1), 23-34. 
Gürses, B. A. (2011). İlköğretim öğrencilerinin çoklu zekâ gelişim düzeylerine ilişkin algıları ve ingilizce öğretmenlerinin çoklu zekâya yönelik uygulamaları. Yayımlanmamış Yüksek Lisans Tezi, Fırat Üniversitesi Eğitim Bilimleri Enstitüsü, Elazı̆̆.

İlhan, M. ve Çetin, B. (2014). LISREL ve AMOS programları kullanılarak gerçekleştirilen yapısal eşitlik modeli (YEM) analizlerine ilişsin sonuçların karşıllaştırılması. Eğitimde ve Psikolojide Ölçme ve Değerlendirme Dergisi, 5(2), 26-42.

İpekli, N. (2013). 10. sınıf öğrencilerinin çoklu zekâ alanlarının belirlenmesi ve matematiğe karşı tutumlarının incelenmesi. Yayımlanmamış Yüksek Lisans Tezi, Balıkesir Üniversitesi Fen Bilimleri Enstitüsü, Balıkesir.

Kabataş, E. (2006). 10. sınıf öğrencilerinin zekâ alanları ile fizik, kimya, biyoloji ve matematik başarıları arasındaki ilişki. Yayımlanmamış Yüksek Lisans Tezi. Atatürk Üniversitesi, Fen Bilimleri Enstitüsü, Erzurum.

Kanat, S. (2008). Görsel sanatlar dersinde çoklu zekâ kuramına dayalı öğretim yönteminin 7. sınıf öğrencilerinin erişisine ve öğrendikleri bilgilerin kalıcılığına etkisi. Yayımlanmamış Yüksek Lisans Tezi, İnönü Üniversitesi Sosyal Bilimler Enstitüsü, Malatya.

Karasar, N. (2003). Bilimsel araştırma yöntemi. (12. Baskı). Ankara: Nobel Yayın Dağıtım.

Kılıç, F. A. (2015). Temel eğitimden ortaöğretime geçiş ortak ve mazeret sınavındaki Türkçe ve matematik alt testlerinin psikometrik özelliklerinin karşılaştııılması. Yayımlanmamış Yüksek Lisans Tezi, Hacettepe Üniversitesi Eğitim Bilimleri Enstitüsü, Ankara.

Kozağaç, B. Z. (2015). Matematik bölümü öğretmen adaylarının çoklu zekâ alanlarının belirlenmesi ve sosyal becerileri ile öğretmenlik mesleğine ilişkin tutumlarının incelenmesi. Yayımlanmamış Yüksek Lisans Tezi, Adnan Menderes Üniversitesi, Sosyal Bilimleri Enstitüsü, Aydın.

Köse, i. A. (2012). Ölçmede güvenirlik. R. N. Çıkrıkçı (Ed.). Eğitimde ölçme ve değerlendirme içinde (s. 91-116). (1. Baskı). Ankara: Elhan Kitabevi.

Kuzgun, Y. (2004). Meslek rehberliği ve danışmanlığa giriş. (2. Baskı). Ankara: Nobel Yayın Dağıtım.

Loori, A. A. (2005). Multiple intelligences: a comparative study between the preferences of males and females. Social Behavior and Personality, 33(1), 77-88.

MEB (2009). Illköğretim matematik dersi (6-8. sınıflar) öğretim programı ve kılavuzu. Ankara.

Nasser, R., Singhal, S. and Abouchedid, K. (2008). Gender differences on self-estimates of multiple intelligences: a comparison between Indian and lebanese youth. Journal of Social Sciences, 16(3), 235-243.

National Council of Teachers of Mathematics NCTM (2000). Principles and standards for school mathematics (3. Edition). America, Virgina: NCTM.

Oral, B. (2001). Branşlarına göre üniversite öğrencilerinin zekâ alanlarının incelenmesi. Eğitim ve Bilim, 26(122),19-31.

Özçelik, D.A. (2016). Eğitimde ölçme ve değerlendirme (5. Baskı). Ankara, Pegem A Yayıncılık.

Schoenfeld, A.H., (1985). Mathematical problem solving, Orlando, FL, Academic Press.

Selçuk, Z., Kayılı, H. ve Okut, L. (2004). Çoklu zekâ uygulamaları. (Geliştirilmiş 4. Baskı). Ankara: Nobel Yayın Dağıtım.

Şengül, S. ve Öz, C. (2008). İlköğretim 6. sınıf kesirler ünitesinde çoklu zekâ kuramına uygun öğretimin öğrenci tutumuna etkisi. Ilköğretim Online, 7(3), 800-813. Web: http://ilkogretimonline.org.tr/index.php/io/article/view/1780/1616 adresinden 20.05.2017 tarihinde alıntılanmıştır.

Talu, N. (1999). Çoklu zekâ kuramı ve eğitime yansımaları. Hacettepe Üniversitesi Eğitim Fakütesi Dergisi, 5, 64-72.

Tekin, M. ve Güllü, M. (2009). Spor lisesi öğrencileri ile genel lise öğrencilerinin çoklu zekâ alanlarının karşılaştırılması. Niğde Üniversitesi Beden Eğitimi ve Spor Bilimleri Dergisi, 3(3), 247-258.

Temiz, N. (2007). Çoklu zekâ kuramı okulda ve sınıfta. Ankara: Nobel Yayın Dağııım.

Yaz, í. (2013). Beden eğitimi ve spor yüksekokulunda okuyan öğrencilerin çoklu zekâ alanları ile holland kişilik tipleri arasındaki ilişkinin araştırılması. Yayımlanmamış Yüksek Lisans Tezi, Gazi Üniversitesi, Eğitim Bilimleri Enstitüsü, Ankara. 
Yenilmez, K. ve Bozkurt, E. (2006). Matematik eğitiminde çoklu zekâ kuramına yönelik öğretmen düşünceleri. Mehmet Akif Ersoy Üniversitesi Eğitim Fakültesi Dergisi, 30, 90-103.

Yenilmez, K. ve Çalışkan, S. (2011). İlköğretim öğrencilerinin çoklu zekâ alanları ile yaratıcı düşünme düzeyleri arasındaki ilişki. Dicle Üniversitesi Ziya Gökalp Eğitim Fakültesi Dergisi, 17, 48-63. 